\title{
CONSTRUCTION OF ADENOVIRAL VECTORS EXPRESSING F AND G GLYCOPROTEINS OF HUMAN RESPIRATORY SYNCYTIAL VIRUS (HRSV)
}

\author{
Ithana Monteiro Kosaka; Cassiano Carromeu; Edison Luiz Durigon; Armando Morais Ventura* \\ Departamento de Microbiologia, Instituto de Ciências Biomédicas, Universidade de São Paulo, São Paulo, SP, Brasil.
}

Submitted: September 15, 2003; Returned to authors: April 28, 2004; Approved: May 20, 2004.

\begin{abstract}
Human Respiratory Syncytial Virus (HRSV) was first characterized in 1957 and has since been recognized as the most common viral cause of severe respiratory tract infection in young infants worldwide. Despite many years of research there is still no effective treatment or any immediate prospect of a vaccine. The HRSV genome is composed of single stranded negative sense RNA and the virion consists of a nucleocapsid packaged within a lipid envelope. The envelope contains spike-like projections, each being a homooligomer of one of three transmembrane viral envelope proteins: the attachment protein G, the fusion protein $\mathrm{F}$ involved in viral penetration and the small hydrofobic protein $\mathrm{SH}$. The aim of this work was to construct two recombinant replication-defective adenoviruses carrying separately $\mathrm{F}$ and $\mathrm{G}$ genes from HRSV. This system was chosen because adenovirus delivers genes into target cells with high efficiency in a variety of cell lines and can be used in vitro and in vivo. In order to obtain the recombinant viruses, we did RT-PCR of RNA extracted from the HRSV A2 strain, the genes F and G were cloned in to pAdeno-X vectors. pAdeno-F and pAdeno-G were transfected in HEK-293 cells for the production of recombinant viruses, that expressed efficiently these two proteins and provide us the means for doing functional assays and immunization tests.
\end{abstract}

Key words: Respiratory Syncytial Virus, adenoviral vectors, protein Expression, HRSV F protein, HRSV G protein

\section{INTRODUCTION}

Human respiratory syncytial virus (HRSV) is a pneumovirus in the family Paramyxoviridae of the order Mononegavirales, the non-segmented negative-strand RNA viruses. HRSV strain A2 genome is 15,222 nucleotides (nt) in length and encodes 10 mRNAs and 11 proteins in the order $3^{\prime}-\mathrm{NS} 1-\mathrm{NS} 2-\mathrm{N}-\mathrm{P}-\mathrm{M}$ $-\mathrm{SH}-\mathrm{G}-\mathrm{F}-\mathrm{M} 2,1 / \mathrm{M} 2,2-\mathrm{L}-5^{\prime}$ (18). The N, $\mathrm{P}$ and L proteins are necessary and sufficient to direct RNA replication (4), whereas processive RNA transcription requires in addition the transcription antitermination factor M2,1 (1). The viral envelope contains three transmembrane glycoproteins: the small hydrophobic SH protein with unknown function, the major attachment $\mathrm{G}$ protein, and the fusion $\mathrm{F}$ protein. The internal matrix protein $\mathrm{M}$ is thought to mediate virion morphogenesis. NS1 and NS2 are considered to be nonstructural proteins and appear to be involved in regulating a balance between transcription and RNA replication (6).

The two major HRSV strain subgroups, A and B, are distinguished primarily by the $\mathrm{G}$ protein, which shows about $50 \%$ aminoacid divergence between subgroups. Thus infection with one subgroup does not confer complete protection against the other (9). Severe lower respiratory tract disease generally occurs only in the first 2 years of life, but this experience does not protect against less severe forms of HRSV infections, such as upper respiratory tract and ear infections (6). HRSV is the leading cause of severe lower respiratory tract illness in newborns and young infants. It is also increasingly

*Corresponding author. Mailing address: Departamento de Microbiologia, Instituto de Ciências Biomédicas II, Laboratório de Vetores Virais, Universidade de São Paulo. Av. Prof. Lineu Prestes, 1374, Cidade Universitária. 05508-900, São Paulo, SP, Brasil. E-mail: amventur@icb.usp.br 
recognized to be an important pathogen in eldery and in immunocompromised patients. Although immunoprophylaxis by parenterally administered antibody is available for high-risk individuals, HRSV lacks an effective antiviral therapy or a licenced vaccine for use in the general population. Thus, the development of a safe and effective vaccine remains an important strategy in the fight against HRSV-associated diseases $(3,16)$.

It has been hypothesized that the immune response induced by HRSV may not be only inadequate but potentially contributory to the development of disease. The initial evidence leading to this hypothesis came from field trials of the first vaccine developed for HRSV, a formalin-innativated whole-virus vaccine given parenterally (5). Experimental vaccines designed to preferentially induce cytotoxic $\mathrm{T}$ lymphocytes also provided resistance to infection, but this effect was short-lived and insuficientlly protective (10).

Two types of recombinant adenovirus vectors have been used for immunization, the E3 (early 3) deleted, able to replicate in the target cells (7), and E1 plus E3 region deleted, defective in replication $(14,15)$. This second strategy, making possible a unique infection in cells with no viral propagation, may be successful in immunization protocols because adenovirus viral capsid proteins will not be produced in large amounts. In this way, there is less interference with the expression of the desired antigen and its presentation to immune system is more likely to mimic natural infection. Thus we are particularly interested in the development of adenovirus-vectored HRSV vaccines for the following reasons: oral adenovirus vaccines have an established safety record; adenoviruses have been developed as high-level expression vectors; and foreign proteins have a correct posttranslational processing (2). In the present paper, we constructed two E1/E3 defective recombinant adenovirus expressing F and G glycoproteins of HRSV A2 (antigenic subgroup A).

\section{MATERIALS AND METHODS}

\section{Viruses and cells}

HRSV strain A2 were grown in HEp-2 cells propagated in MEM (Minimal Essential Medium) supplemented with 10\% of Fetal Bovine Serum and titrated by sincitia formation. All recombinant adenoviruses were cultured in HEK-293 cells.

\section{RT-PCR of HRSV F and G genes}

In breaf, total RNA was extracted from HEp-2 infected with A2 strain of HRSV, using Trizol LS (Invitrogen, San Diego, CA, USA). cDNA was prepared using Random Primers and reverse transcriptase (Superscript ${ }^{\mathrm{TM}}$ - Invitrogen) and stored at $-70^{\circ} \mathrm{C}$. The PCR of genes was made using Taq polimerase (Invitrogen) with the specific following primers: RSF5 (5' GCT CTA GAA ACC ATG GAG T/CTG CTA/G ATC C 3'); RSF3 (5' ATAAGA
ATG CGG CCG CCT AGT TAC TAA ATG CAA TAT T 3'); RSG5 (5' - AAG GAAAAA AGC GGC CGC GCAAAC ATG TCC AAAAAC -3'); RSG3 (5' GGG GTA CCT TAC TAC TGG CGT GG/TT GTG TTG G 3'); which were designed adding flanking restriction sites. These restriction sites are indicated in bold underlined sequences, $\mathrm{XbaI}$ in RSF5, NotI in RSF3 and RSG5, KpnI in the RSG3. The conditions for PCR were: $94^{\circ} \mathrm{C}-5$ minutes; 30 times: $94^{\circ} \mathrm{C}-1$ minute, $55^{\circ} \mathrm{C}-1$ minute, $72^{\circ} \mathrm{C}-1$ minute and a final cycle $72^{\circ} \mathrm{C}-5$ minutes. The DNA fragments were analyzed by electrophoresis in agarose gels, and staining with ethidium bromide.

\section{Cloning into an intermediate plasmid}

Cloning of RT-PCR product was perfomed by using "TOPO ${ }^{\circledR}$ XL PCR Cloning Kit" (Invitrogen) and checked by restriction analysis and sequencing. The resulting plasmids were called pTOPOF and pTOPOG. The bacterial colonies containing recombinant plasmids were selected in LB medium containing kanamicin and the plasmid DNA was extracted and purified by standard methods.

\section{Cloning of $\mathrm{F}$ and $\mathrm{G}$ genes in pShuttle and expression in mammalian cells}

F or G genes were removed from pTOPOF, by digestion with $K p n I$ and $X b a \mathrm{I}$, or pTOPOG by digestion with $K p n I$ and NotI. These fragments were ligated in to pShuttle vector, from the Adeno-X Expression System Kit (Clontech, Palo Alto, CA, USA), digested in the same sites, generating pShuttleF and pShuttleG. To verify the expression, these plasmids were transfected into HEK-293 cells using the method of calcium co-precipitation ("Kit CalPhos ${ }^{\mathrm{TM}}$ Clontech), according to the manufacturer's instructions. The cells were scraped with a rubber policeman 36 hours after, collected, suspended in PBS, dropped in slides and fixed with acetone. The slides were incubated with a mixture of monoclonal antibodies for detection of respiratory viruses (Chemicon, Temecula, CA, USA) for 30 minutes, washed and incubated a second mouse antibody anti-IgG fluorescein-conjugated goat anti human (Sigma, Saint Louis, MO, USA). The slides were mounted and viewed using a fluorescence microscope (Zeiss) with epillumination.

\section{Adeno-X expression system}

The construction of plasmids and the recombinant viruses were performed according to the manufacture's instructions, following the method of Mizuguchi and Kay (12). In brief, pShuttleF and pShuttleG were digested with Pi-SceI and I-CeuI and the expression cassette was subcloned in a plasmid containing the adenoviral DNA deleted in E1 and E3 regions. The plasmids were analyzed by PCR and digestion with restriction enzymes and then the correct clones amplified. After digestion with $\mathrm{PacI}$ to release the virus vector genome, they 
were transfected in HEK-293, which supplies E1 products in trans, for the packing of recombinant viruses. With the appearance of the cytopathic effect, cells and supernatants were harvested and cell debris removed by low-speed centrifugation. Virus-containing supernatants were stored at $-70^{\circ} \mathrm{C}$. To confirm the presence of the genes into recombinant adenoviruses, a PCR was perfomed using the same primers for gene amplification.

\section{Expression of proteins by recombinant adenoviruses}

To demonstrate that transduced HEK-293 cells were transcribing the F and G genes, a RT-PCR was perfomed in cells collected 48 hours after transduction. The protein expression was demonstrated in the same HEK-293 cells fixed for immunofluorescence, performed as described above.

\section{RESULTS}

The A2 subgroup A strain was grown in Hep2 cells and the cDNAs were obtained by RT-PCR from the total RNA extracted from infected cells using Random Primers. PCR to amplify the F and $\mathrm{G}$ genes was performed using primer pairs annealing at their ends. The obtained PCR products (Fig. 1a) were cloned into the intermediate vector pTOPO generating pTOPOF and pTOPOG. The gene integrity was checked by sequencing and all the mutations detected in both genes were silent and located in non-conserved regions (data not shown).
The construction of pShuttleF and pShuttleG was done by the subcloning of fragments from pTOPOF and pTOPOG, obtained by double digestion with NotI and KpnI or XbaI and KpnI respectively, into pShuttle (Fig. 2). To demonstrate the functionality of these vectors They were transfected in HEK293 cells and the protein expression was monitored by immunofluorescence, which gave the expected results (data not shown).

Subcloning of the expression cassettes from pShuttle vectors, excised with the rare cutting enzymes PI-Sce and ICeuI, was done into Adeno-X vector which contains the whole adenovirus type 5 genome with deletions in E1 and E3 regions (data not shown). The obtained plasmids, AdenoF and AdenoG, were digested with PacI before the transfeccion in HEK-293 in order to release the adenoviral vector genomes, and guarantee the correct replication and packing.

After transfection of HEK-293 cells with the AdenoF and G plasmids, we observed viral plaques in 14-16 days. To characterize the adenoviral vectors, a PCR to detect $F$ and $G$ genes was done in DNA extracted from HEK-293 cells transduced with them after the second passage. The presence of the correct products was obtained (data not shown). In order to detect gene transcription in transduced cells, a RT-PCR was performed and the correct products were also obtained (Fig. 1b). The F and $G$ protein expression was confirmed by their detection with indirect immunofluorescence at transduced HEK-293 cytoplasmatic membrane (Fig. 3).
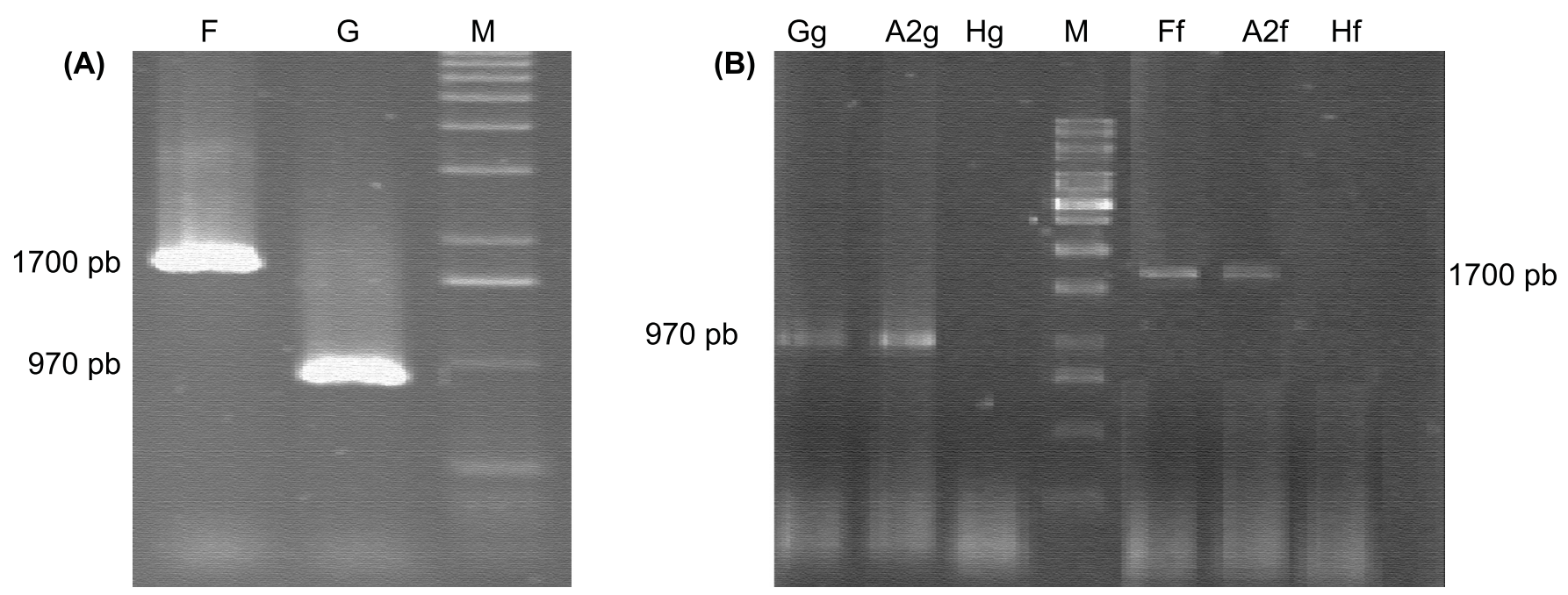

Figure 1. F and G gene amplification. In panel a) RT-PCR was performed in RNA extracted from HRSV A2 prototype infected HEp2 cells for F or G genes. In panel b) cDNAs were obtained by reverse transcription of the RNA from cells transduced with recombinant adenoviral vectors. PCR was performed with the primers for F (f) or G (g) genes as described in Material and Methods. RNAs were extracted from: HEK-293 transduced with AdenoF (F) or AdenoG (G); Hep2 infected with HRSV A2 (A2); and untransduced HEK293 (H). The molecular weight marker (M) is the $1 \mathrm{~Kb}$ DNA ladder (Invitrogen). 


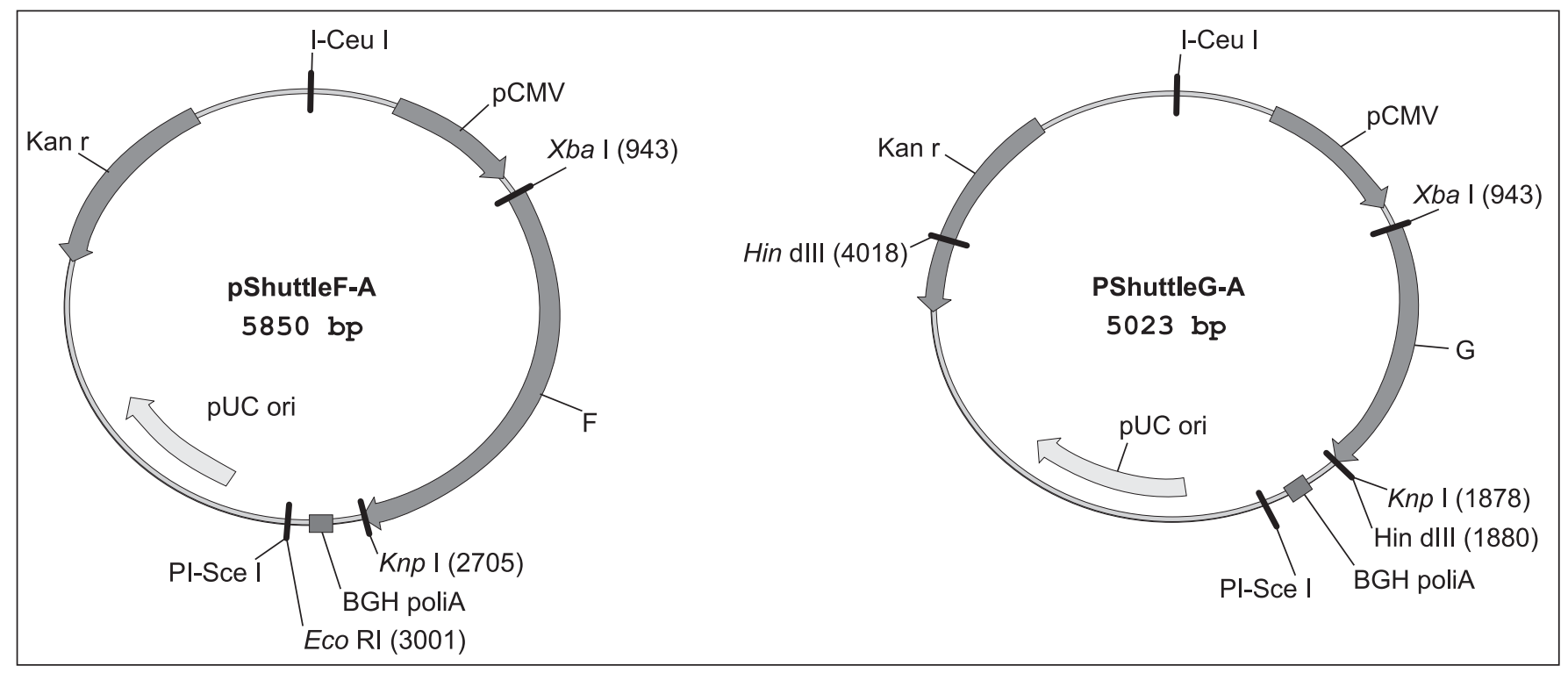

Figure 2. Schema of pShuttleF and pShuttleG vectors.
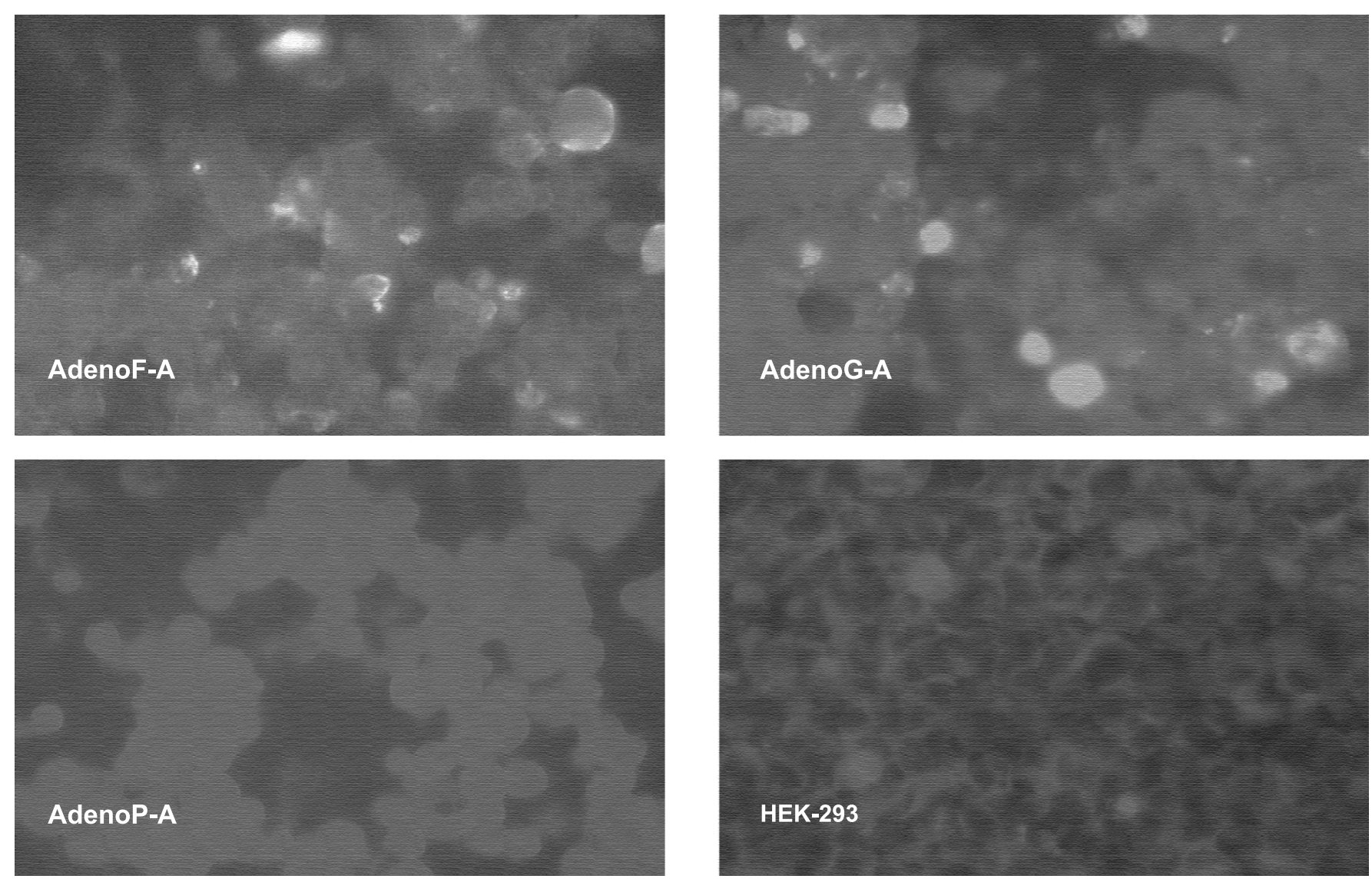

Figure 3. Indirect Immunofluorescence of transduced HEK 293 cells. The panels illustrate cells that reacted with monoclonal antibodies. Top panel on left, AdenoF; top panel on right, AdenoG; bottom panel on left, AdenoP (negative control); bottom panel on right HEK 293 (untransduced cells). The cells were processed 48 hours after transduction for Indirect Immunofluorescence. 


\section{DISCUSSION}

In this report, we describe for the first time the construction of replication-defective adenoviral vectors expressing $F$ and $G$ envelope glycoproteins of HRSV, which are the principal targets of immune response. Recombinant viruses represent a particularly promising avenue for development of vaccines and research. Expression of antigens by virus vectors has proven to be a productive approach for studying in vitro and in vivo immune responses. An important feature of almost all recombinant viruses is the ability to induce not just humoral, but also cell-mediated immunity (8).

Replication-defective adenoviral vectors, deleted in E1 region, can be successfully propagated only in HEK-293 cells, which provide E1 products in trans. Thus, in target cells there is no viral vector propagation and no production of big amounts of capsid proteins. Their main advantage is the expression almost exclusive of the desired transgene (17). Preliminary studies with recombinant replicative adenoviruses (only E3 deleted), expressing HRSV $F$ and $G$ genes, showed initial promising results, however when tested in dogs and a chimpanzee the response to the HRSV antigens was not protective (7). On the other hand, E1 deleted vectors have been used successfully for immunization against other viral antigens $(14,15)$, and may be a good alternative against HRSV envelope glycoproteins too.

Adenoviral vectors have been demonstrated to infect $100 \%$ of the target cells (8), but in our register about $70 \%$ of the cells only are fluorescent (Fig. 3, top panels). This should be due to the cell harvesting technique used for the fixation on the slide, in which several layers of cells are superimposed. We observed initially that $100 \%$ of the cells were positive, but while the slide pictures were recorded the fluorescence of the cell layer below was being quickly exhausted. The F and $\mathrm{G}$ glycoproteins expression was also confirmed by detection of gene transcription by RT-PCR (Fig.1b).

An optimal HRSV vaccine would combine genetic stability, satisfactory growth in vitro, high attenuation in vivo and a satisfactory level of immunogenicity. Future studies will evaluate the immunogenicities of the adenoviral vectors and the pShuttle vectors (as DNA vaccine) obtained during the constructions described here. In our laboratory, we have been using adenovirus vectors for the expression of several genes $(11,13)$, and we are developing adenoviral vectors expressing the other structural proteins of HRSV (SH, P, N, L and M). Currently, we are doing experiments associating these vectors with the aim of developing an ideal immunization protocol.

\section{ACKOWLEDGEMENTS}

This work was supported by grants from FAPESP (process number 01/14076-9) for M.Sc. scholarship and CNPq. We are grateful to Prof. Carlos Frederico Martins Menck for sequencing and support.

\section{RESUMO}

\section{Construção de vetores adenovirais expressando as glicoproteínas F e G de vírus respiratório sincicial humano (HRSV)}

O Vírus Sincicial Respiratório Humano (HRSV) foi isolado e caracterizado pela primeira vez em 1957 e é considerado como o patógeno viral mais freqüente do trato respiratório de bebês e crianças. Apesar de muitos anos de pesquisa, não há ainda um tratamento específico ou uma vacina licenciada. Seu genoma é composto por uma fita simples de RNA polaridade negativa e o vírion consiste em um nucleocapsídeo empacotado por um envelope lipídico. O envelope contém projeções, chamadas espículas, constituídas de homoligômeros de uma das 3 glicoproteínas de membrana: a proteína de ligação $G$ ("attachment"), a proteína de fusão F ("fusion") e a proteína SH ("small hydrofobic"). O objetivo deste trabalho foi construir dois adenovirus recombinantes defectivos em replicação expressando separadamente os genes F e G do HRSV. Este sistema foi escolhido porque os vetores adenovirais possuem a capacidade de inserir genes em uma grande variedade de linhagens celulares in vitro e in vivo. Para obtenção destes vetores adenovirais, um RT-PCR de RNA extraído do protótipo A2 de HRSV foi feito e os genes $F$ e $G$ clonados em vetores pAdeno-X. pAdeno-F e pAdeno-G foram transfectados em células HEK-293 para a produção do vírus recombinante, que expressaram corretamente essas duas proteínas constituem-se ferramentas para imunização e estudos funcionais.

Palavras-chave: Vírus Respiratório Sincicial, vetores adenovirais, expressão protéica, proteína HRSV F, proteína HRSVG

\section{REFERENCES}

1. Collins, P.L.; Hill, M.G.; Cristina, J.; Grosfeld, H. Transcription elongation factor of respiratory syncytial virus, a nonsegmented negative-strand RNA virus. Proc. Natl Acad. USA, 93:81-85, 1996.

2. Davis, A.R.; Kostek, B.; Mason, N.B. Expression of Hepatitis B surface antigen with a recombinant adenovirus. Proc Natl Acad Sci USA, 82:7560-7564, 1985.

3. Falsey, A.R. Respiratory syncytial virus infection in older persons. Vaccine, Nov 16(18): 1775-8, 1998.

4. Grosfeld, H.; Hill, M.G.; Collins, P.L. RNA replication by respiratory syncytial virus (RSV) is directed by the $\mathrm{N}, \mathrm{P}$ and $\mathrm{L}$ proteins, transcription also occurs under these conditions but requires RSV superinfection for efficient synthesis of full-length mRSN. J. Virol., 69: 5677-5686, 1995.

5. Graham, B.S.; Rutigliano, J.A.; Johnson, T.R. Respiratory Syncytia Vírus Immunobiology and Pathogenesis. Virology, 297:1-7, 2002. 
6. Hall, C.B. Prospects for a respiratory syncytial virus vaccine. Science, 265: 1393-1394, 1994.

7. Hsu, K.H.; Lubeck, M.D.; Davis, A.R.; Bhat, R.A.; Selling, B.H.; Bhat, B.M.; Mizutani, S.; Murphy, B.R.; Collins, P.L.; Chanock, R.M.; Hung, P.P. Immunogenicity of recombinant adenovirus-respiratory syncytial virus vaccines with adenovirus types 4,5 , and 7 vectors in dogs and a chimpanzee J. Infect. Dis, 166(4): 769-75, 1992.

8. Imler, J.L. Adenovirus vectors as recombinant viral vaccines. Vaccine, 13: 1143-1151, 1995.

9. Johnson, P.R.; Olmsted, R.A.; Prince, G.A.; Murphy, B.R.; Alling, D.W.; Walsh, E.E. Antigenic relatedness between glycoproteins of human respiratory syncytial virus subgroups $\mathrm{A}$ and $\mathrm{B}$ : evaluation of the contributions of $\mathrm{F}$ and $\mathrm{G}$ glycoproteins to immunity. J. Virol., 61: 3163-6, 1987.

10. Krempl, C.; Murphy, B.R.; Collins, P.L. Recombinante Respiratory Syncytial Virus with the $\mathrm{G}$ and $\mathrm{F}$ genes shifted to the promoterproximal positions. J. Virol., 76(23): 11931-11942, 2002.

11. Magalhães G.S.; Muotri, A.R.; Marchetto, M.C.N.; Menck, C.F.M.; Ventura, A.M. An Adenovirus Vector Containing the Suicide Gene Thymidine Kinase for a Broad Application in Cancer Gene Therapy. Memórias do Instituto Oswaldo Cruz, 97(4): 547-552, 2002.

12. Mizuguchi, H.; Kay, M.A. Efficient construction of a recombinant adenovirus vector by an improved in vitro ligation method. Hum Gen Ther, 9: 2577-83, 1998.

13. Muotri, A.R.; Marchetto, M.C.N.; Zerbini, L.F.C.; Libermann T.A.; Ventura, A.M.; Sarasin A.; Menck C.F.M. Complementation of the DNA repair deficiency in human xeroderma pigmentosum group A and C cells by recombinant adenovirus-mediated gene transfer. Human Gene Therapy, 13(15): 1833-44, 2002.

14. Pinto, A.R.; Fitzgerald, J.C.; Gao, G.P.; Wilson, J.M.; Ertl, H.C. Induction of $\mathrm{CD} 8+\mathrm{T}$ cells to an HIV-1 antigen upon oral immunization of mice with a simian E1-deleted adenoviral vector. Vaccine, 22(5-6): 697-703, 2004.

15. Shiver, J.W.; Fu, T.M.; Chen, L.; Casimiro, D.R.; Davies, M.E.; Evans, R.K.; Zhang, Z.Q.; Simon, A.J.; Trigona, W.L.; Dubey, S.A.; Huang, L.; Harris, V.A.; Long, R.S.; Liang, X.; Handt, L.; Schleif, W.A.; Zhu, L.; Freed, D.C.; Persaud, N.V.; Guan, L.; Punt, K.S.; Tang, A.; Chen, M.; Wilson, K.A.; Collins, K.B.; Heidecker, G.J.; Fernandez, V.R.; Perry, H.C.; Joyce, J.G.; Grimm, K.M.; Cook, J.C.; Keller, P.M.; Kresock, D.S.; Mach, H.; Troutman, R.D.; Isopi, L.A.; Williams, D.M.; Xu, Z.; Bohannon, K.E.; Volkin, D.B.; Montefiori, D.C.; Miura, A.; Krivulka, G.R.; Lifton, M.A.; Kuroda, M.J.; Schmitz, J.E.; Letvin, N.L.; Caulfield, M.J.; Bett, A.J.; Youil, R.; Kaslow, D.C.; Emini, E.A. Replication-incompetent adenoviral vaccine vector elicits effective anti-immunodeficiency-virus immunity. Nature: 415(6869): 331-5, 2002.

16. Simoes, E.A. Respiratory syncytial virus infection The Lancet, 354: 847-52, 1999.

17. Ventura, A.M. Adenovirus vectors and their application in gene therapy. Virus Reviews and Research, 5: 7-12, 2000.

18. Zhang, L.; Peeples, M.E.; Boucher, R.C.; Collins, P.L.; Pickles, R.J. Respiratory syncytial virus infection of human airway epithelial cells is polarized, specific to ciliated cells, and without obvious cytopathology. J. Virology, 76(11): 5354-66, 2002. 